\title{
Selective Modulation of Some Forms of Schaffer Collateral-CA1 Synaptic Plasticity in Mice With a Disruption of the CPEB-1 Gene
}

\author{
Juan M. Alarcon, ${ }^{1,4}$ Rebecca Hodgman, ${ }^{3}$ Martin Theis, ${ }^{1,2}$ Yi-Shuian Huang, ${ }^{3}$ \\ Eric R. Kandel, ${ }^{1,2}$ and Joel D. Richter ${ }^{3}$ \\ ${ }^{1}$ College of Physicians and Surgeons of Columbia University and ${ }^{2}$ Howard Hughes Medical Institute and Center for Neurobiology \\ and Behavior, Columbia University, New York, New York 10032, USA; ${ }^{3}$ Program in Molecular Medicine, University \\ of Massachusetts Medical School, Worcester, Massachusetts 01605, USA
}

\begin{abstract}
CPEB-1 is a sequence-specific RNA binding protein that stimulates the polyadenylation-induced translation of mRNAs containing the cytoplasmic polyadenylation element (CPE). Although CPEB-1 was identified originally in Xenopus oocytes, it has also been found at postsynaptic sites of hippocampal neurons where, in response to $N$-methylD-aspartate receptor activation, it is thought to induce the polyadenylation and translation of $\alpha$ CaMKII and perhaps other CPE-containing mRNAs. Because some forms of synaptic modification appear to be influenced by local (synaptic) protein synthesis, we examined long-term potentiation (LTP) in CPEB-1 knockout mice. Although the basal synaptic transmission of Schaffer collateral-CAl neurons was not affected in the knockout mice, we found that there was a modest deficit in LTP evoked by a single train of $100 \mathrm{~Hz}$ stimulation, but a greater deficit in LTP evoked by one train of theta-burst stimulation. In contrast, LTP evoked by either four trains of $100 \mathrm{~Hz}$ stimulation or five trains of theta-burst stimulation were not or were only modestly affected, respectively. The deficit in LTP evoked by single stimulation in knockout mice appeared several minutes after tetanic stimulation. Long-term depression (LTD) evoked by $1 \mathrm{~Hz}$ stimulation was moderately facilitated; however, a stronger and more enduring form of LTD induced by paired-pulse $1 \mathrm{~Hz}$ stimulation was unaffected. These data suggest that CPEB-1 contributes in the translational control of mRNAs that is critical only for some selected forms of LTP and LTD.
\end{abstract}

Recent studies indicate that local protein synthesis can contribute to certain forms of synaptic plasticity. Two distinct but overlapping mechanisms are thought to account for how new proteins come to reside at the stimulated synapse. In one, signals originating at an activated synapse travel to the cell body and induce new transcription; the encoded proteins are subsequently synthesized in the cell body and are distributed evenly within the cell. The activity of these protein products is then spatially restricted to the stimulated synapses by marking or tagging signals that may also require local protein synthesis (Goelet et al. 1986; Sossin 1996; Frey and Morris 1997; Martin et al. 1997; Casadio et al. 1999; Barco et al. 2002; Martin and Kosik 2002). In the other mechanism, new transcription is not required, and local protein synthesis is sufficient. In each case, new proteins are synthesized locally at stimulated synapses by the translation of localized mRNA. This mechanism was suggested by observations that dendritic shafts and spines contain polyribosomes, tRNAs, initiation factors, and specific mRNAs (Steward and Levy 1982; Steward and Falk 1986; Chicurel et al. 1993; Miyashiro et al. 1994; Crino and Eberwine 1996; Tiedge and Brosius 1996; Steward 1997), and it is supported by recent studies in Aplysia and in the rat hippocampus showing that the application of inhibitors of protein synthesis to dendrites abrogates long-lasting changes in synaptic efficacy (Bailey et al. 1996; Kang and Schuman 1996; Martin et al. 1997; Schuman 1997; Aakalu et al. 2001).

In early vertebrate development, the translational activation of some maternal mRNAs is regulated by cytoplasmic polyade-

\section{${ }^{4}$ Corresponding author.}

E-MAIL jma129@columbia.edu; FAX (212) 543-5474.

Article and publication are at http://www.learnmem.org/cgi/doi/10.1101/ Im.72704. nylation. Here, dormant mRNAs containing a $3^{\prime}$ untranslated region cis sequence, the cytoplasmic polyadenylation element (CPE), have short poly-(A) tails, which when elongated in response to an exogenous cue, stimulate translation (McGrew et al. 1989; Paris et al. 1991). Cytoplasmic polyadenylation is regulated most proximally by CPEB-1, a sequence-specific RNA binding protein whose activity is stimulated once it is phosphorylated by aurora A, a serine/threonine kinase (Hake and Richter 1994; Stebbins-Boaz et al. 1996; Mendez et al. 2000a,b). Polyadenylation, in turn, stimulates translation by causing the dissociation of maskin, a CPEB-1 and eIF4E-interacting factor, from eIF4E. This dissociation is a prerequisite for the proper assembly of the translation initiation complex, which includes eIF4E, eIF4G, eIF4A, eIF3, and the 40s ribosomal subunit, on the $5^{\prime}$ end of the mRNA (Stebbins-Boaz et al. 1999; Cao and Richter 2002).

CPEB-1 has also been detected at postsynaptic sites of hippocampal neurons, and it is believed to participate in the $\mathrm{N}$ methyl-D-aspartate (NMDA) receptor-dependent polyadenylation-induced $\alpha$ CamKII mRNA translation that occurs in the synapto-dendritic compartment (Wu et al. 1998; Wells et al. 2001; Huang et al. 2002). Such observations suggest a potentially causal link between CPEB-1, local mRNA translation, and synaptic plasticity (Mendez and Richter 2001; Richter 2001; Richter and Theurkauf 2001; Richter and Lorenz 2002). To explore this connection, we investigated whether synaptic plasticity in Schaffer collateral-CA1 synapses is affected in mice that have a disrupted CPEB-1 gene (Tay and Richter 2001). We examined different forms of LTP and found a deficit in LTP evoked by a single train of stimulation. In contrast, there was no, or a very small, deficit, with stronger forms of LTP produced by repeated trains of stimulation. Similarly, in long-term depression (LTD), facilitation was 
observed, but only with a weak and not with a strong protocol. These data suggest that ablation of the CPEB-1 gene only affects some forms of synaptic plasticity, whereas other forms remain intact possibly because of the compensatory activity of other CPEB family members or by activation of CPEB-1-independent pathways.

\section{RESULTS}

\section{Anatomy and Basal Synaptic Transmission in CPEB-1 KO Mice}

Northern blot for $C P E B-1$ from brain total RNA showed that CPEB-1 RNA was absent in the CPEB-1 KO mice (Fig. 1A). Nissl staining of sagittal sections of CPEB-1 KO brains revealed no gross anomalies (Fig. 1B). Moreover, cultured hippocampal neurons from these animals appeared normal in all respects, although a minor reduction of synapse number or a change in spine morphology may not necessarily be detected using this assay (Y.-S. Huang and J.D. Richter, unpubl.). We determined whether synaptic transmission was impaired in CPEB-1 KO mice by exploring basic features of Schaffer collateral-CA1 synaptic responses. Input-output relationships of the magnitude of the field excitatory postsynaptic potential (fEPSP) slope (Fig. 1C, left graph, wild type vs. CPEB- $1 \mathrm{KO}, P=.83$ ) or the presynaptic fiber volley amplitude (Fig. 1C, right graph, wild type vs. CPEB-1 KO $P=.76$ ) were not significantly different in CPEB-1 KO as compared with wild-type mice. We similarly found no significant difference between knockout and wild-type mice in paired pulse facilitation (Fig. 1D, wild type vs. CPEB-1 KO $P=.51$ ).

\section{LTP Deficit in CPEB-1 KO Mice in Response to $100 \mathrm{~Hz}$ Stimulation and Theta-Burst Stimulation}

We analyzed knockout mice for possible deficits in LTP by first focusing on four different forms: one train of theta-burst stimulation (TBS), five trains of TBS, one train of $100 \mathrm{~Hz}$, and four trains of $100 \mathrm{~Hz}$ (Arai et al. 1994; Huang and Kandel 1994; Staubli and Otaky 1994; Castro-Alamancos et al. 1995; Nguyen and Kandel 1996; Patterson et al. 2001). We found that LTP evoked by a single train of $100 \mathrm{~Hz}$ stimulation was moderately impaired in the CPEB-1 KO mice (Fig. 2A, 20-30 min: wild type 151\% $\pm 9 \%$ vs. CPEB- $1 \mathrm{KO} 129 \% \pm 6 \%, P=.03 ; 60-70 \mathrm{~min}$ : wild type $119 \% \pm 5 \%$ vs. CPEB-1 KO $112 \% \pm 9 \%, P=.3)$. Furthermore, when LTP was evoked by a single train of TBS, we observed a greater deficit (Fig. 2C, 20-30 min: wild type 202\% $\pm 9 \%$ vs.

\section{A}

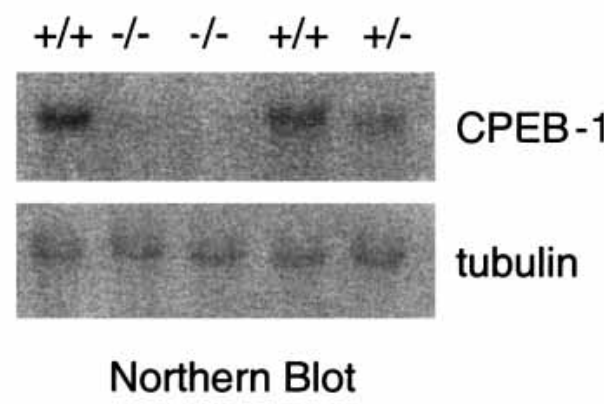

\section{B}
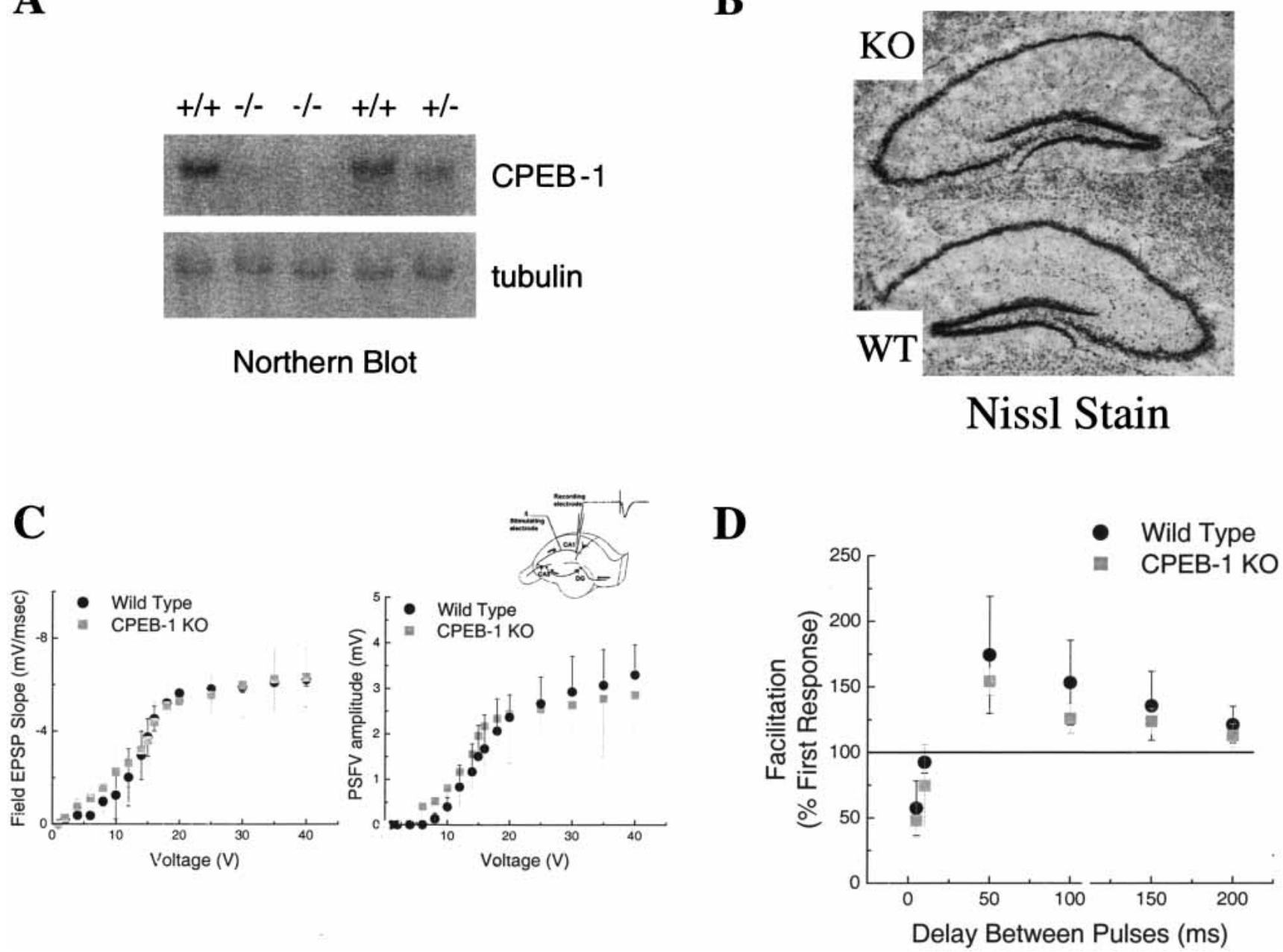

Figure 1 (A) Northern blot for CPEB-1 in the brain from wild-type and CPEB-1 KO mice. Tubulin is shown as loading control. Wild type (+/+), CPEB-1 KO $(-/-)$, CPEB-1 KO heterozygote $(+/-)$. (B) Hippocampal section showing Nissl staining from a wild-type and a CPEB-1 KO mouse. (C) Input-output curve (left) and PSFV versus voltage plot (right) $(\mathrm{n}=12)$. Inset: Scheme of the mouse hippocampal slice preparation. $(D)$ Scatter plot shows paired pulse facilitation responses $(n=12)$. Interpulse interval, msec: $5,10,50,100,150$, and 200 . In all figures, the data points represent mean \pm SD. 
A

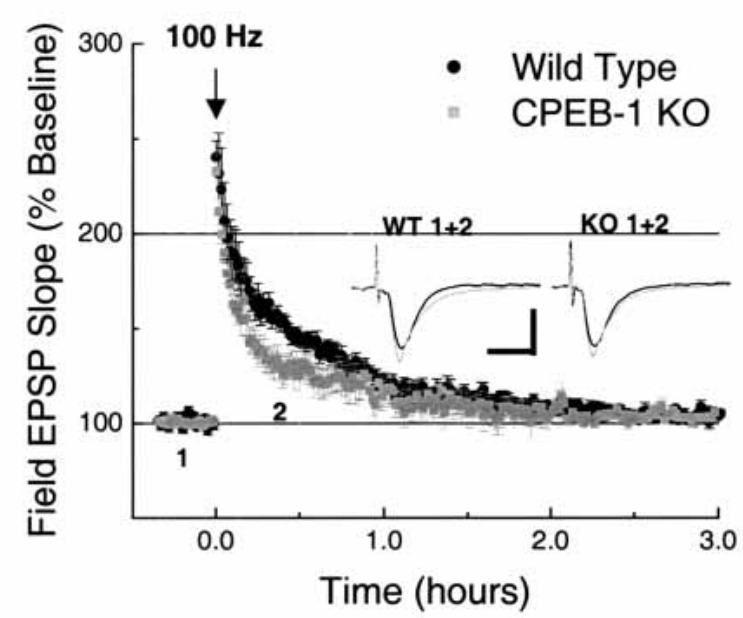

C

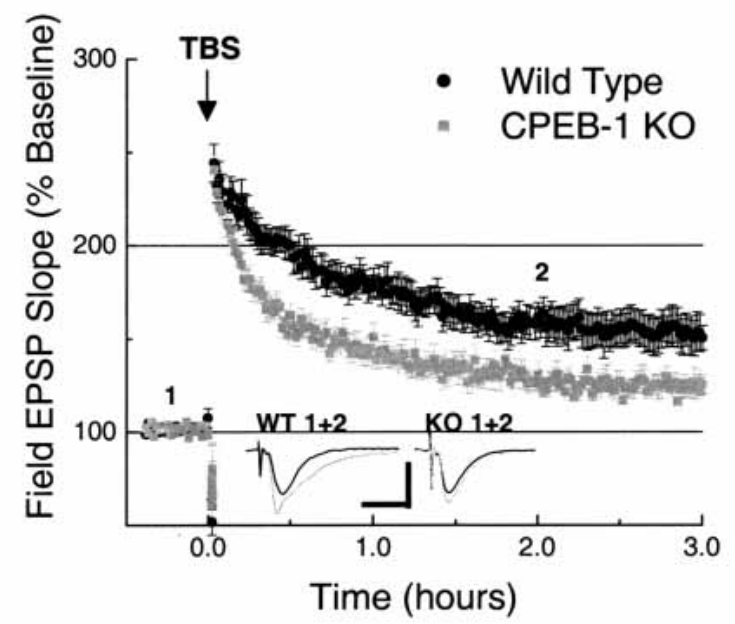

B
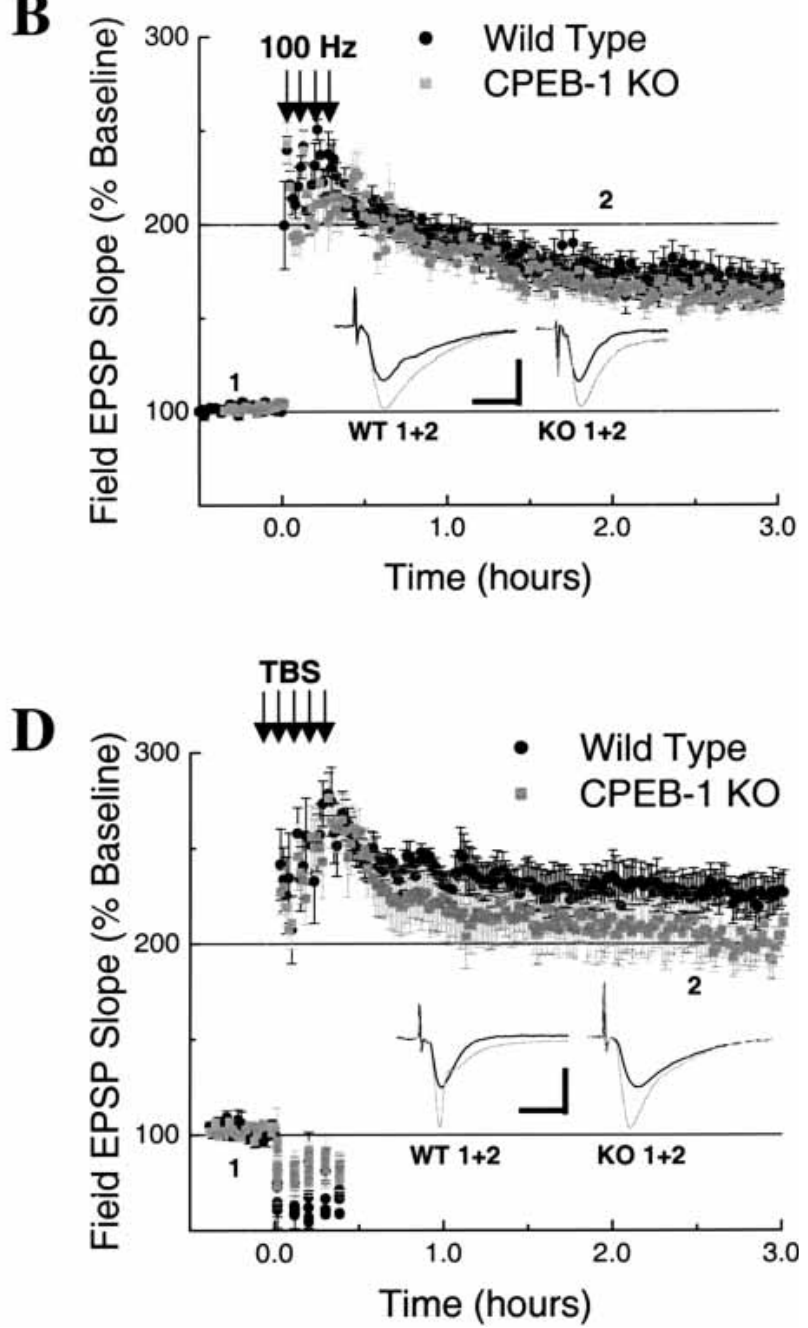

Figure 2 (A) Long-term potentiation (LTP) evoked by one train of $100 \mathrm{~Hz}$ in CPEB-1 KO and wild-type mice $(\mathrm{n}=12 / 12)$. (B) LTP evoked by four trains of $100 \mathrm{~Hz}$ in CPEB-1 KO and wild-type mice $(n=8 / 8)$. (C) LTP evoked by one train of TBS in CPEB-1 KO and wild-type mice $(n=10 / 10)$. (D) LTP evoked by five trains of TBS in CPEB-1 KO and wild-type mice $(n=8 / 8)$. Each arrow represents a train of electrical stimulation. TBS: theta-burst stimulation. In all figures the data points represent mean \pm SE. Traces represent baseline (black line, 1) and after $100 \mathrm{~Hz}$ stimulation or TBS (gray line, 2) fEPSPs from wild-type (WT) and CPEB-1 KO (KO) mice. Calibration bars: $3 \mathrm{mV}, 10 \mathrm{~ms}$.

CPEB-1 KO $164 \% \pm 10 \%, P=.004 ; 60-70 \mathrm{~min}:$ wild type $177 \% \pm 6 \%$ vs. CPEB- 1 KO $141 \% \pm 8 \%, P=.001)$. In both forms of LTP the deficit was not observed immediately, but rather several minutes after tetanus (Fig. 2A, 1-5 min: wild type $215 \% \pm 20 \%$ vs. CPEB- 1 KO $198 \% \pm 22 \%, P=.65$; Fig. 2 C, $1-5$ min: wild type $232 \% \pm 8 \%$ vs. CPEB- 1 KO $224 \% \pm 11 \%$, $P=.36)$. Interestingly, forms of LTP evoked by multiple and spaced stimuli were less affected in CPEB-1 KO mice. Whereas LTP evoked by four trains of $100 \mathrm{~Hz}$ was unaltered in the CPEB-1 KO mice (Fig. 2B), LTP evoked by five trains of TBS showed a very slight decrease only observed after 2 hr of LTP expression (Fig. 2D).

\section{Two Temporally Separate Deficits in LTP in CPEB-1 KO Mice}

Because LTP evoked by five trains of TBS showed a rather modest deficit compared with LTP evoked by one train of TBS, we tested whether the latter deficit would gradually be overcome by increasing numbers of trains of stimulation. We compared the av- eraged amplitude of LTP evoked by one, two, three, and five trains of TBS (Figs. 3A,B and 2C,D) calculated from three different time frames (20-30, 90-120, and 150-180 min). We found that LTP induced by one train of TBS showed a deficit in all three time frames but not LTP induced by two, three, or five trains of TBS (Fig. 3C,D,E). Although there was a trend suggesting that LTP evoked by three trains of TBS was more affected than LTP evoked by two trains of TBS at the 150-180-min time frame (Fig. 3E), such a difference was not statistically significant (two trains of TBS-LTP, wild type $169 \% \pm 8 \%$ vs. CPEB- 1 KO $151 \% \pm 11 \%$, $P=.39$; three trains of TBS-LTP, wild type $197 \% \pm 10 \%$ vs. CPEB-1 KO $173 \% \pm 12 \%, P=.06$ ). A deficit in LTP at the 150 180-min time frame was significant only for LTP evoked by five trains of TBS (Fig. 3E; five trains of TBS-LTP: wild type $226 \% \pm 6 \%$ vs. CPEB-1 KO $200 \% \pm 10 \%, P=.02$ ). Our data show that LTP evoked by either two or three trains of TBS were unaffected in CPEB-1 KO mice, and that LTP evoked by one and five trains of TBS were affected at different time frames. These results suggest that CPEB- 1 ablation might differentially affect 
A

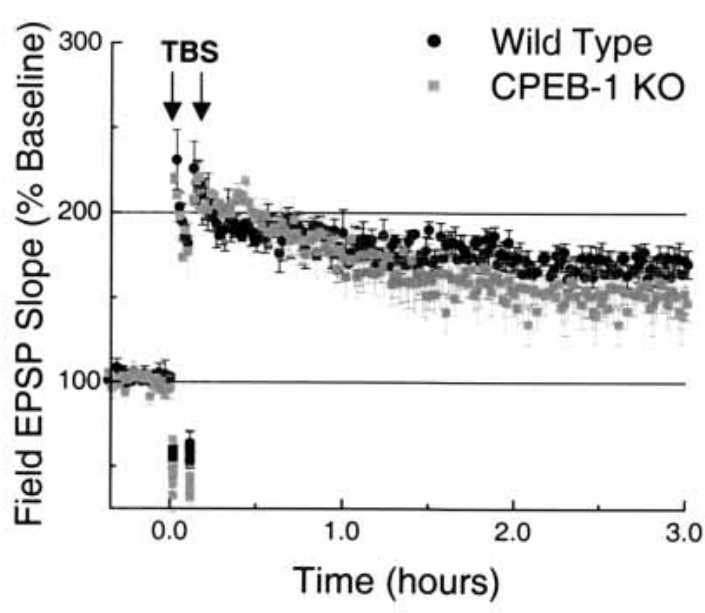

B

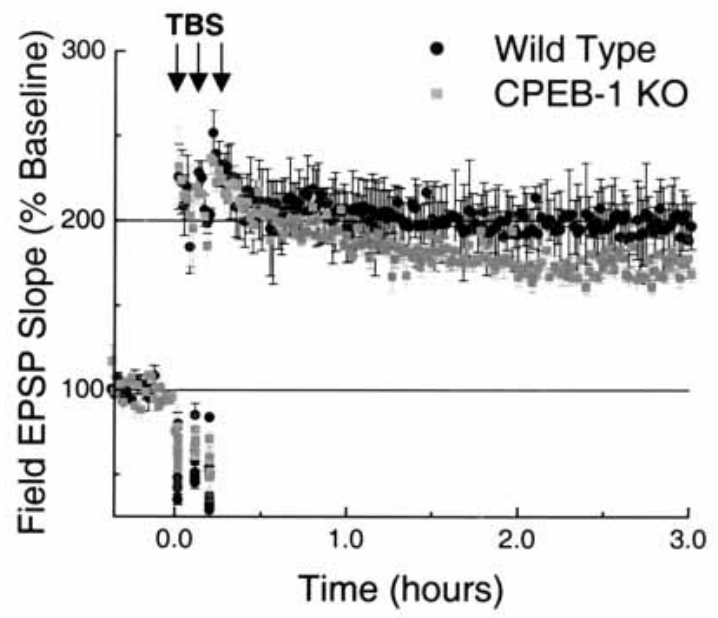

C

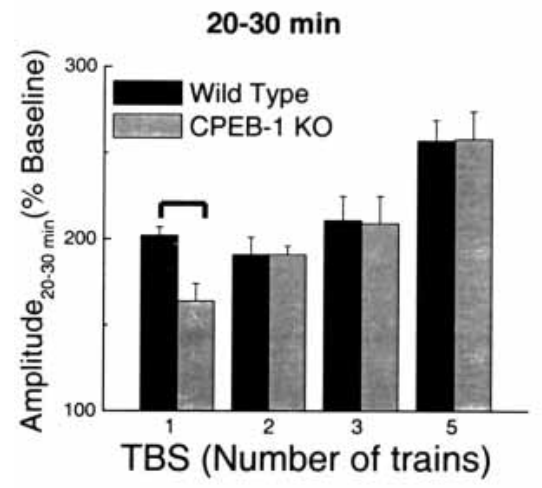

D

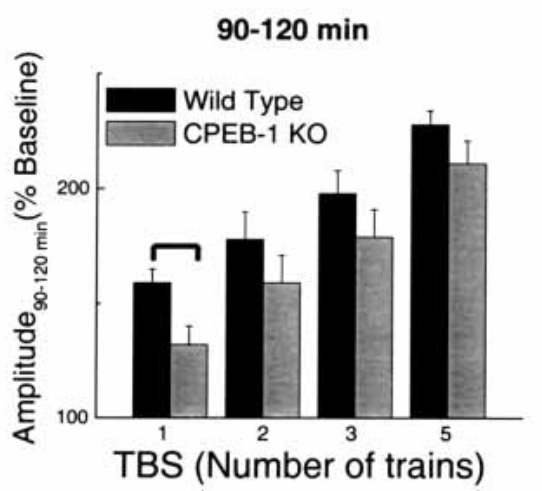

$\mathbf{E}$

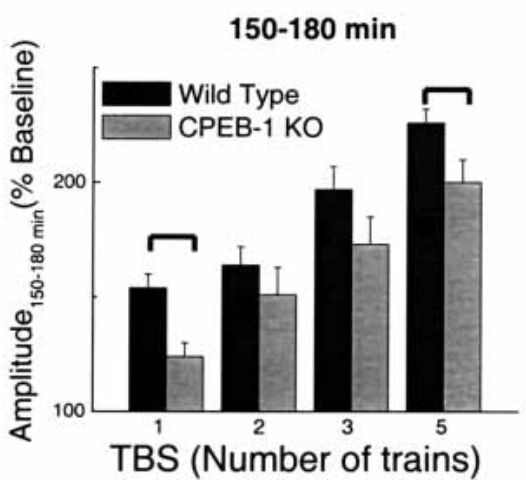

Figure $3(A)$, Long-term potentiation (LTP) evoked by two trains of theta-burst stimulation in CPEB-1 KO and wild-type mice $(n=6 / 6)$. (B) LTP evoked by three trains of theta-burst stimulation in CPEB-1 KO and wild-type mice $(n=5 / 5)$. Each arrow represents a train of electrical stimulation. In all figures the data points represent mean \pm SE. Histograms showing amplitude of LTP evoked by 1-5 TBS for the 20-30 min (C), 90-120 min (D), and 150-180 min $(E)$ for CPEB-1 KO and wild-type mice. Each bracket represents statistical significance $(p<0.05)$ between two columns. Data-columns represent mean $\pm S D$.

two temporally separate processes during LTP expression, depending on the stimulation protocol. Analysis of LTP evoked by increasing trains of $100 \mathrm{~Hz}$ stimulation (one to four trains) showed that only LTP evoked by one train of $100 \mathrm{~Hz}$ stimulation was impaired (data not shown).

\section{Frequency Response Curve Is Not Shifted in CPEB-1 KO Mice}

So far we have interpreted our results in the framework of differential responses to different stimulation patterns. However, one can imagine other frameworks for interpreting the data. For example, it appears that effects are weakened with stronger inducing stimuli. Thus, perhaps the effect of the CPEB-1 KO is to shift the Bienenstock-Cooper-Munro (BCM) relationship (Bienenstock et al. 1982) to the right, with no effect on LTP with the strongest induction protocols. The BCM relationship allows for determining the LTP/LTD threshold. Thus, a shift to the right would indicate a displacement in the LTP/LTD threshold in the same direction. We examined the $\mathrm{BCM}$ relationship by generating frequency response curves (FRC) from wild-type and CPEB-1 KO mice. FRCs were constructed by testing three different electrical protocols: 10, 5, and $1 \mathrm{~Hz}$ stimulation (for each one, 900 pulses were delivered; Fig. 4A,B,C). Two time frames were chosen for comparison between genotypes: 20-30 and 50-60 min (data points from LTP evoked by $100 \mathrm{~Hz}$ stimulation were added to Figs. 4D and 4E only as reference). We found that FRCs were not shifted for any of the analyses (Fig. 4D,E), suggesting that lack of CPEB-1 did not shift the BCM relationship.

\section{LTD in CPEB-1 KO Mice}

LTD induced by $1 \mathrm{~Hz}$ was more enduring in CPEB- $1 \mathrm{KO}$ mice than in wild-type mice (Fig. 4C, 50-70 min: wild type 98\% $\pm 3 \%$ vs. CPEB-1 KO $87 \% \pm 3 \%, P=.01)$. This result prompted us to investigate whether LTD evoked by a stronger induction protocol would perhaps be enhanced in CPEB-1 KO mice. We induced LTD by using the paired-pulse $1 \mathrm{~Hz}$ protocol (one train of pulses delivered at $1 \mathrm{~Hz}$ for $15 \mathrm{~min}$; each train consisting of two pulses with 50 msec interpulse interval), a protocol that resulted in LTD lasting many hours in the CA1 area of the hippocampus of adult mice (Oliet et al. 1997; Kemp et al. 2000). We found no difference in LTD amplitude between wild-type and CPEB-1 KO mice (Fig. $4 \mathrm{~F}, 50-70 \mathrm{~min}$ : wild type $63 \% \pm 4 \%$ vs. CPEB- $1 \mathrm{KO} 66 \% \pm 6 \%$; $P=.13)$. 
A

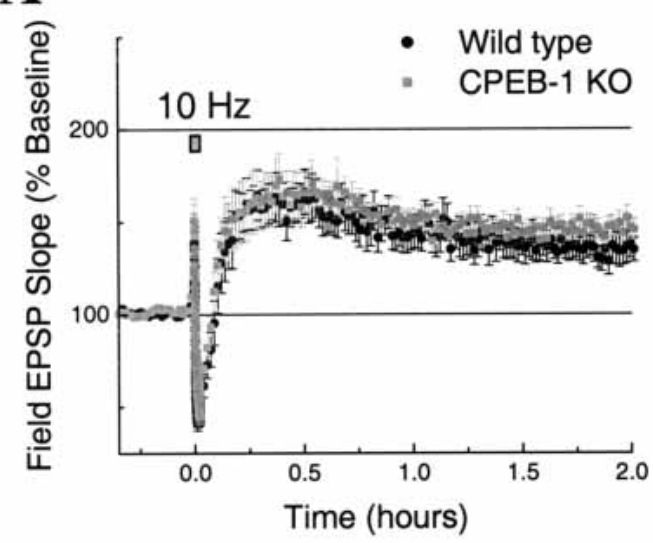

B

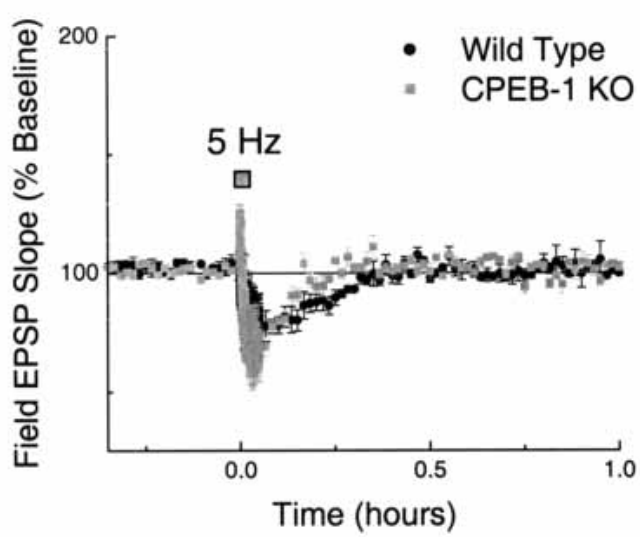

C

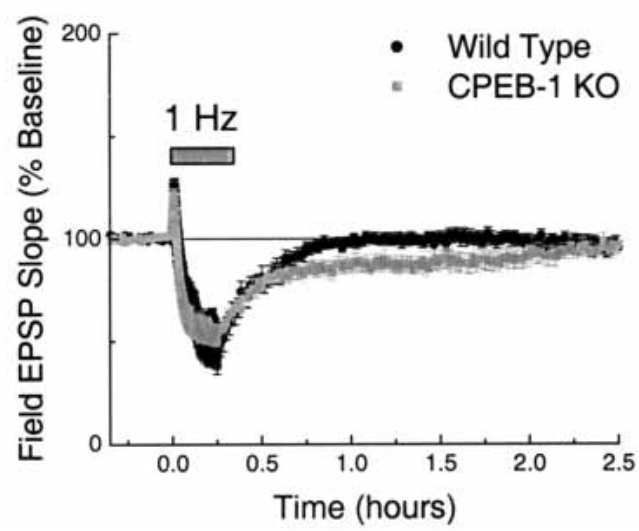

D

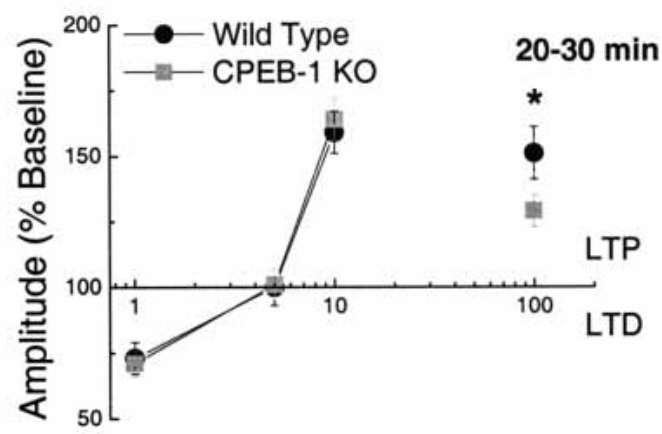

$\mathbf{E}$

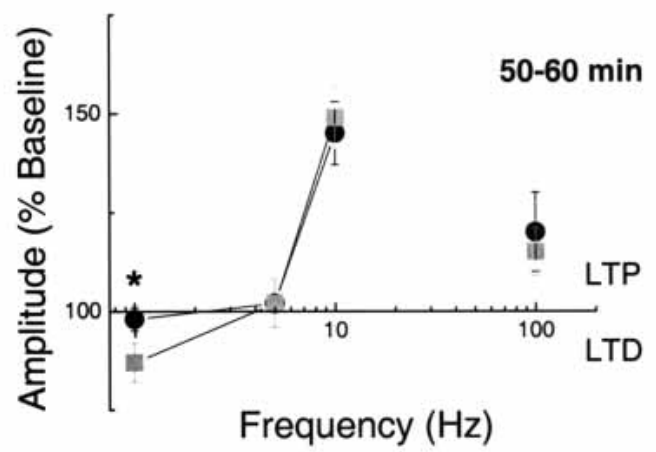

F

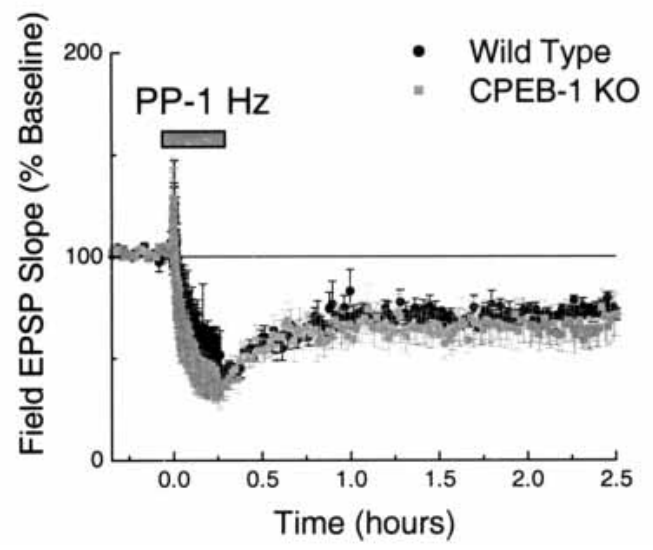

Figure 4 (A) Long-term potentiation evoked by $10 \mathrm{~Hz}(90 \mathrm{sec})$ stimulation in CPEB-1 KO and wild-type mice $(\mathrm{n}=6 / 6)$. (B) Short-term depression evoked by $5 \mathrm{~Hz}(180 \mathrm{sec})$ stimulation in CPEB-1 $\mathrm{KO}$ and wild-type mice $(\mathrm{n}=6 / 6)$. (C) Long-term depression evoked by $1 \mathrm{~Hz}(15 \mathrm{~min})$ stimulation in CPEB-1 KO and wild-type mice $(n=10 / 8)$. Frequency response curves for the 20-30 min $(D)$ and 50-60 min $(E)$ time traces from CPEB-1 KO and wild-type mice. $(F)$ Long-term depression evoked by paired-pulse $(50 \mathrm{msec}$ interpulse interval) $1 \mathrm{~Hz}$ (15 min) stimulation in CPEB-1 KO and wild-type mice $(n=10 / 8)$. In all figures the data points represent mean \pm SE.

Theta-Burst LTP and Rapamycin-Sensitive Pathways in LTP

LTP induced by TBS is thought to rely on local (i.e., synaptic) protein synthesis (Patterson et al. 1996; Gartner and Staiger 2002;

Tang et al. 2002). We therefore compared the knockout pheno- type observed in TBS-evoked LTP (which may be related to polyadenylation-induced translation) with the LTP phenotype that is observed after disruption of a mechanism for dendritic translation that may be independent of polyadenylation. We chose rapamycin, an inhibitor of the FRAP/mTOR kinase signaling

\section{Learning \& Memory}

www.learnmem.org 
pathway that appears to broadly affect dendritic translation (Tang and Schuman 2002) through its activity on S6 kinase, the eIF4E binding proteins (eIF4EBPs), or the terminal oligopyrimidine element found in the 5' untranslated regions of a number of mRNAs (Beretta et al. 1996; Brown and Schreiber 1996; Brunn et al. 1997; Sabatini et al. 1997; Martin et al. 2000b; Gingras et al. 2001).

Rapamycin $(0.5 \mu \mathrm{M})$ treatment reduced the amplitude of LTP evoked by a single train of TBS in both wild-type and CPEB-1 KO mice (Fig. 5A, left and right graphs). Rapamycin also affected the late, but not the early, expression of LTP (1-10 min: wild-type control, $232 \% \pm 11 \%$, wild-type rap, $230 \% \pm 10 \%, P=.96 ; 10$ 50 min: wild-type control, $193 \% \pm 14 \%$, wild-type rap, $186 \% \pm 16 \%, P=.14 ; 120-150$ min: wild-type control, $173 \% \pm 4.2 \%$, wild-type rap: $110 \% \pm 3 \%$. $P<.05)$. The LTP profile from untreated CPEB-1 KO animals and that of wildtype animals treated with rapamycin were virtually identical (Fig. 5B, 1-10 min: wild-type rap 230\% $\pm 10 \%$ vs. CPEB-1 KO $218 \% \pm 20 \%, P=.4 ; 10-50$ min: wild-type rap $186 \% \pm 16 \%$ vs. CPEB-1 KO 163\% $\pm 15 \% ; P=.03 ; 120-150$ min: wild-type rap $110 \% \pm 3 \%$ vs. CPEB-1 KO $126 \% \pm 5 \% ; P=.02$ ).

When we extended our analysis to the LTP evoked by five trains of TBS (Fig. 6A), we again saw that rapamycin affected the late expression of LTP (25-45 min: wild-type control,
$247 \% \pm 7.8 \%$, wild-type rap, $235 \% \pm 10 \% ; P=.5 ; 120-150 \mathrm{~min}:$ wild-type control, $227 \% \pm 3 \%$, wild-type rap, $170 \% \pm 3 \%$, $P<.05)$. In this case, the deficit observed in CPEB-1 KO mice only partially mimicked the rapamycin effect in wild-type mice (Fig. $6 \mathrm{~B}, 25-45$ min: wild-type rap, $235 \% \pm 10 \%$ vs. CPEB- $1 \mathrm{KO}$ $240 \% \pm 13 \% ; P=.6 ; 120-150$ min: wild-type rap, $170 \% \pm 7 \%$ vs. CPEB-1 KO 204\% $\pm 9 \%, P=.006)$. Moreover, the LTP evoked by four trains of $100 \mathrm{~Hz}$ stimulation, which was not impaired in CPEB-1 KO mice, was also sensitive to rapamycin (Raymond et al. 2002; data not shown).

To further explore the rapamycin-sensitive pathway, we analyzed the ability of human brain-derived neurotrophic factor (BDNF) to induce potentiation in CPEB-1 KO mice. BDNF is thought to be necessary for LTP evoked by TBS and to evoke synaptic potentiation that depends on the rapamycin-sensitive pathway (Kang and Schuman 1996; Patterson et al. 1996; Aakalu et al. 2001; Gartner and Staiger 2002; Tang et al. 2002). We found that rapid perfusion $(\sim 9 \mathrm{~mL} / \mathrm{min})$ of BDNF $(50 \mathrm{ng} / \mathrm{mL})$ evoked similar potentiation in both wild-type and CPEB-1 KO mice (Fig. $6 \mathrm{C}$; 40-80 min: wild type, $140 \% \pm 12 \%$; CPEB- $1 \mathrm{KO}$, $148 \% \pm 11 \%, P=.24)$. These data suggest that although there may be some overlap between CPEB-1 and rapamycin-sensitive pathways there is also an important independence regarding their contribution during the expression of different forms of LTP.
A

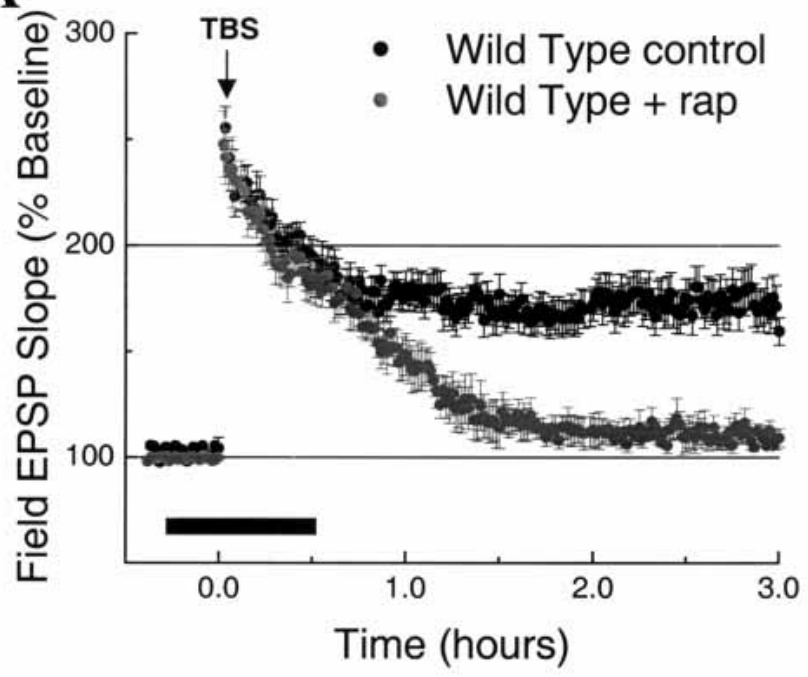

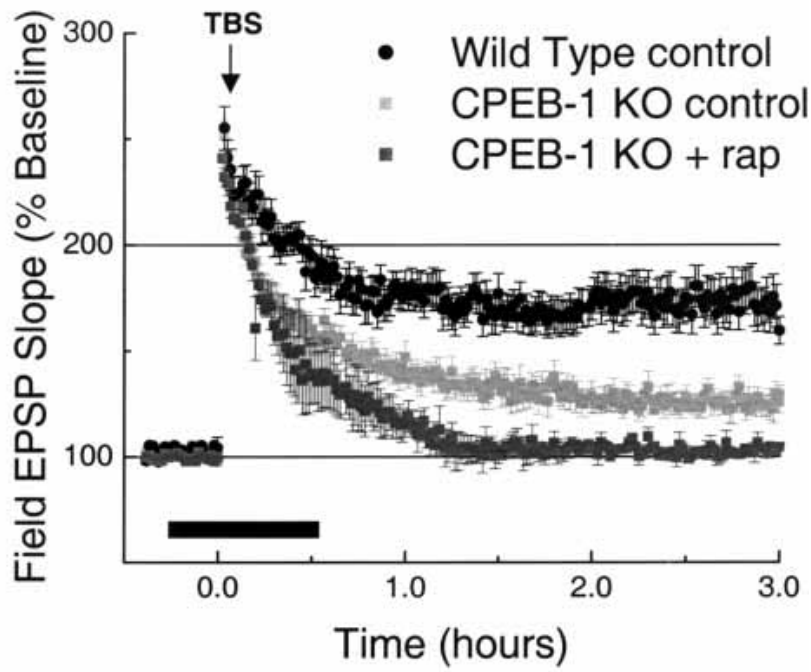

B

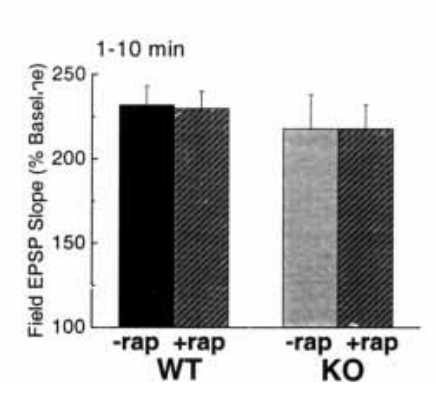

1 TBS
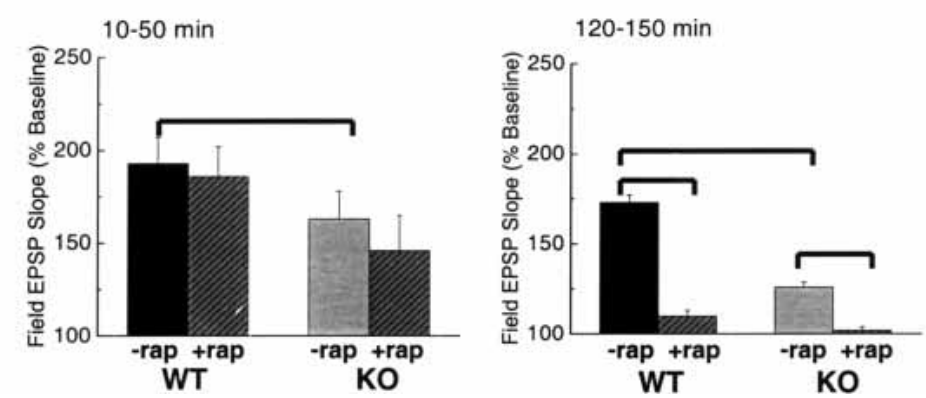

Figure 5 (A) Rapamycin effect on a single train of theta-bursts-evoked long-term potentiation (theta-burst stimulation) in wild type (left) and CPEB-1 KO (right) mice. The horizontal bar represents the time of rapamycin application. Wild-type control $(n=5)$, wild-type rap $(n=6)$, CPEB-1 KO control $(n=5)$, CPEB-1 KO rap $(n=6)$. Data points represent mean \pm SE. (B) Amplitude histogram for three time frames $(1-10,10-50$, and 120-150 min) for each Long-term potentiation showed in $(A)$. Data points represent mean \pm SD. Bars show statistical significance $(P<.05)$ between two data sets.

Learning \& Memory 
A

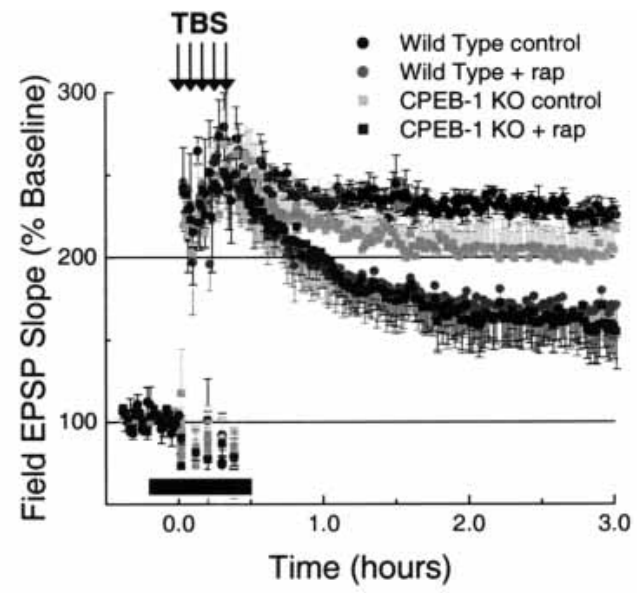

C

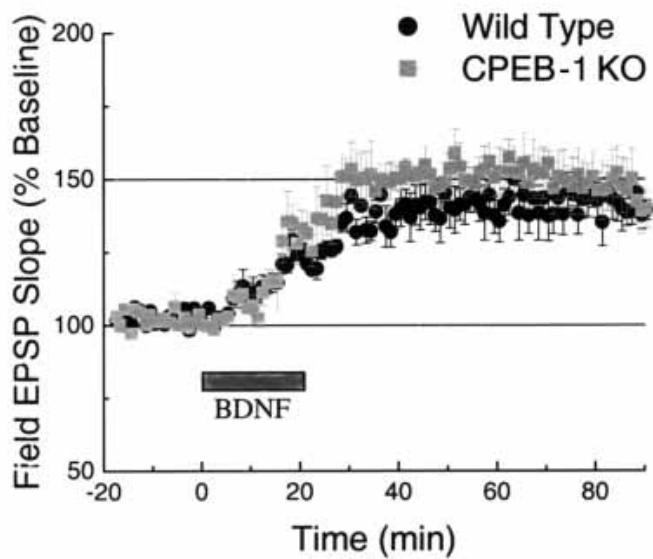

B

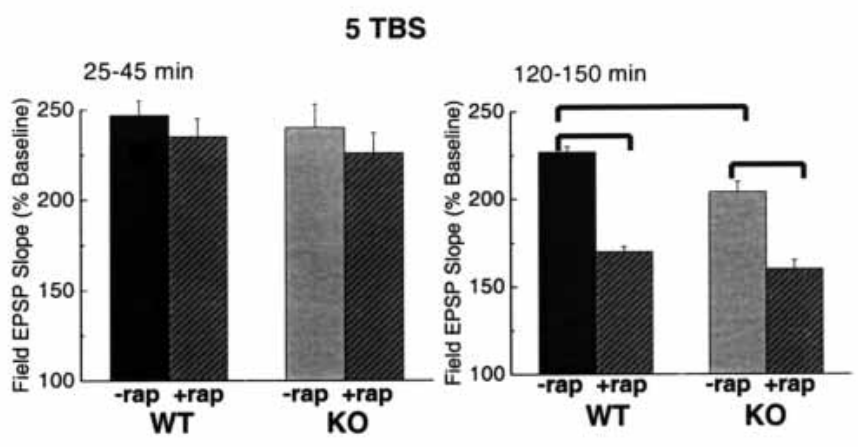

Figure $6(A)$ Rapamycin effect on five trains of theta-bursts-evoked long-term potentiation in wild-type and CPEB-1 KO mice. The horizontal bar represents the time of rapamycin application. Wild-type control $(n=5)$, wild-type rap $(n=6), C P E B-1$ KO control $(n=5)$, CPEB- 1 KO rap $(n=6)$. Data points represent mean \pm SE. (B) Amplitude histogram for two time frames (25-45 min and 120-150 min) for each long-term potentiation shown in $(A)$. Data points represent mean \pm SD. Bars show statistical significance $(P<.05)$ between two data sets. (C) Human brain-derived neurotrophic factor-evoked long-term potentiation in wild-type and CPEB-1 KO mice $(n=5)$. The horizontal bar represents the time of human brain-derived neurotrophic factor application.

\section{Fast Pre- and Postsynaptic Responses Are Not Altered in CPEB-1 KO Mice}

Concomitant to our working hypothesis, our data could also suggest that the early deficit $(<1 \mathrm{hr})$ in LTP evoked by tetanic stimulation observed in CPEB- $1 \mathrm{KO}$ mice could be the result of a failure in some mechanisms necessary for LTP induction. To test this idea, we examined two short-term forms of synaptic plasticity that are recruited during the induction of LTP: synaptic depression (Geppert et al. 1994) and tetanus-induced depolarization (Winder et al. 1998). The first form represents the extent of the presynaptic fatigue that develops during a 2-sec train at $14 \mathrm{~Hz}$ (NMDA, mGlu, and $\mathrm{GABA}_{\mathrm{A}}$-receptor mediated responses were blocked with (D)-APV, (s)-MCPG, and picrotoxin, respectively). We found that the degree of fEPSP fatigue was not statistically different in CPEB-1 KO versus wild-type mice (Fig. 7A, $P=.07$ ). The second form represents the extent of depolarization (likely to be NMDA-receptor mediated) during and after strong tetanic stimulation induced by a 1-sec train at $100 \mathrm{~Hz}$ (Fig. 7B). Neither the maximal peak amplitudes nor the areas below each trace were found to be statistically different between wild-type and CPEB-1 KO mice (Fig. 7C, columns-bar plots; Peak: $P=.81$, Area: $P=.19$ ). These data suggest that the fast, transient-responding pre- and postsynaptic mechanisms are similar in CPEB-1 KO and wild- type mice. However, our data do not rule out the possibility that other mechanisms necessary for LTP induction could be altered in the CPEB-1 KO animals.

\section{LTP Evoked by Synaptic Capture Is Affected in CPEB-1 KO Mice}

Finally, we examined a form of LTP that is evoked by means of synaptic capture of LTP (Frey and Morris 1997, 1998a; Martin et al. 1997). Expression of captured LTP is thought to bypass the requisite for activation of those transcriptional and protein synthesis mechanisms that are necessary for the consolidation of the late phase of LTP (Frey and Morris 1998b; Casadio et al. 1999). Thus, the capturing synapses are only required to be sufficiently activated to engage the productive use of preexistent de novo gene products (for further detail on synaptic capture hypothesis, see Frey and Morris [1998b]). A recent work by Barco et al. (2002) confirmed this hypothesis and also demonstrated that captured LTP was moderately dependent on protein synthesis (Barco et al. 2002). Given this evidence, we tested the effect of the disrupted CPEB-1 gene on captured LTP. We found that both wild-type and CPEB-1 KO mice showed captured LTP in the S2 pathway (Fig. 8, lower graph). We found that there was no statistically significant difference between wild-type and CPEB- $1 \mathrm{KO}$ mice during the

\section{Learning \& Memory}

www.learnmem.org 
A

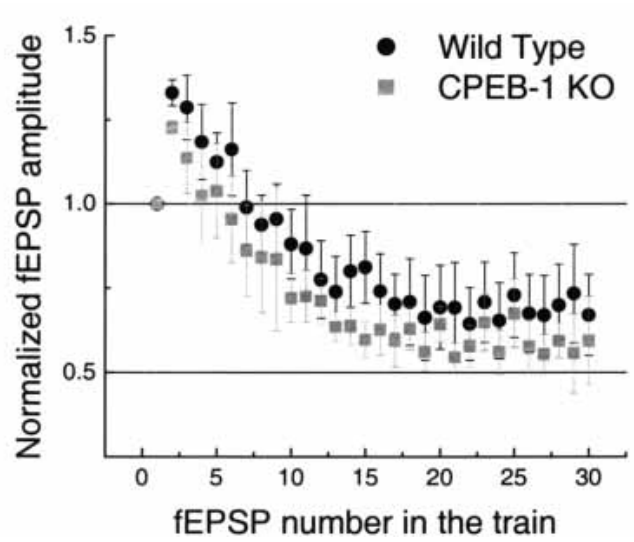

B

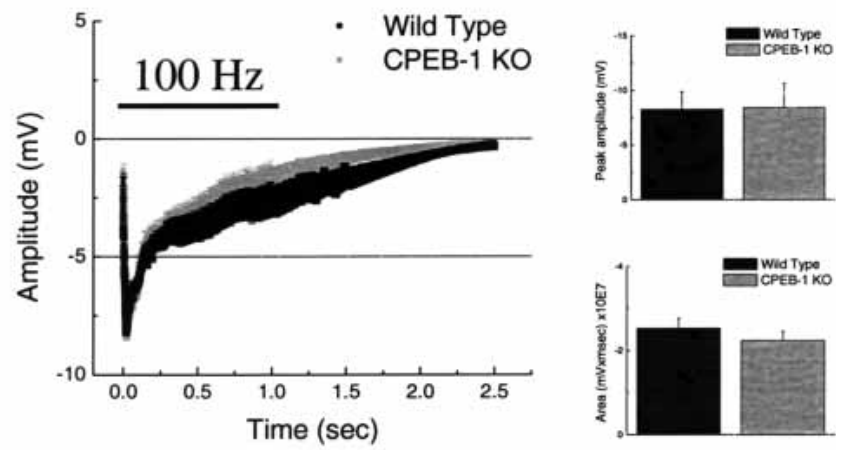

Figure 7 (A) Synaptic fatigue responses during a train at $14 \mathrm{~Hz}$ in CPEB-1 $\mathrm{KO}$ and wild-type mice $(\mathrm{n}=12 / 9)$. Data normalized to the first response. (B) Field depolarization induced by $100 \mathrm{~Hz}$ stimulation for $1 \mathrm{sec}$ (horizontal bar) in CPEB-1 KO and wild-type mice $(\mathrm{n}=8 / 8)$. Column/bar plot shows peak amplitudes obtained from (B) (upper graph). Column/bar plot shows area under the curves obtained from (B) (lower graph). In all figures the data points represent mean \pm SD.

early expression of the captured LTP (Fig. 8, S2, 45-75 min: wild type, $207 \% \pm 11 \%$; CPEB- $1 \mathrm{KO}, 197 \% \pm 18 \%, P=.16)$. However, with time there was a very modest but apparently progressive decrease in the captured LTP amplitude. This decrease was statistically significant only after $75 \mathrm{~min}$ of captured LTP induction (Fig. 8, S2, 120-210 min: wild type, 173\% \pm 6\%; CPEB-1 KO, $148 \% \pm 6 \%, P<0.05 ; \mathrm{S} 1,120-210 \mathrm{~min}$ : wild type $179 \% \pm 6 \%$ vs. CPEB- $1 \mathrm{KO} 165 \% \pm 12 \%, P=.75)$.

\section{DISCUSSION}

\section{Possible Role of CPEB-1 in Synaptic Plasticity}

Increasing experimental evidence supports a link between synaptic activity and translation activation (Brown and Schreiber 1996; Angenstein et al. 1998; Wu et al. 1998; Martin et al. 2000a; Scheetz et al. 2000). Although synaptic translation could be regulated at multiple levels, recent evidence showing that one activity ascribed to CPEB-1 (cytoplasmic polyadenylation) was stimulated on NMDA receptor activation strongly suggests a link between this RNA modification and LTP. Indeed, this possible link is underscored by the observation that a key player in LTP, $\alpha$ CaMKII, is translationally regulated at the synapses in part by cytoplasmic polyadenylation (Wu et al. 1998; Richter 2001; Wells et al. 2001; Huang et al. 2002). The results presented in this study, that CPEB-1 KO mice (Tay and Richter 2001) show altered LTP and LTD, establish the involvement of CPEB-1 in synaptic plasticity. Our results can be interpreted to suggest that $C P E B-1$ deficiency only makes a difference with weak or moderately weak stimulus protocols.

We suggest that the large deficit found in LTP elicited by a single train of TBS in the knockout mice might involve the role of CPEB-1 in activity-dependent protein synthesis mechanisms driven by cytoplasmic polyadenylation. However, the discrete phenotype on LTP elicited by one train at $100 \mathrm{~Hz}$ and on LTD elicited by one train at $1 \mathrm{~Hz}$ in the knockout mice might correlate with CPEB-1 activities involved in sustaining constitutive levels of synaptic protein synthesis. It should also be noted that another CPEB-1 activity, the transport of CPE-containing RNA to dendrites (Huang et al. 2003) might also have an effect on synaptic plasticity.

If CPEB-1-mediated protein synthesis is affected in CPEB-1 KO mice, then why do protein synthesis-dependent forms of LTP elicited by stronger stimulus protocols show none or a rather modest phenotype? Recent evidence has shown that CPEB-1 is the founding member of a family of four proteins that are similar in the RNA binding region of the protein, which includes two RNA recognition motifs and a zinc finger (Hake and Richter 1994; Stebbins-Boaz et al. 1996; Hake et al. 1998; Mendez and Richter 2001; Mendez et al. 2002; Kurihara et al. 2003; Theis et al. 2003). RNA encoding these other CPEB family members is found in the brain (Huang et al. 2003; Theis et al. 2003), and thus, it is tempting to speculate that the other putative CPEB-1-like proteins in the brain might have some role in synaptic plasticity, perhaps even by compensating for the CPEB-1 deficiency in the knockout animals. This view is consistent with

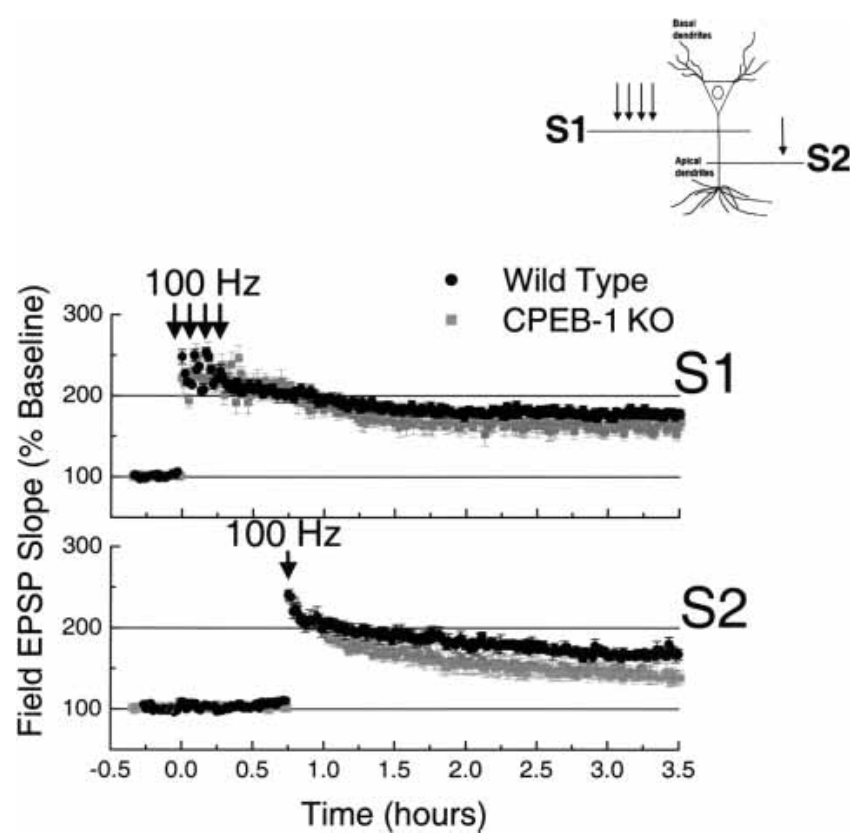

Figure 8 Top panel, Late phase of long-term potentiation evoked by four trains of $100 \mathrm{~Hz}$ stimulation delivered to pathway S1 observed in CPEB-1 KO and wild-type mice. Bottom panel, Capture of late long-term potentiation evoked by one train of $100 \mathrm{~Hz}$ delivered to the pathway S2 observed in CPEB-1 KO and wild-type mice. Data points represent mean \pm SE $(n=5 / 5)$. The scheme represents the two pathways (S1 and S2) stimulated by electrodes placed in the proximal and distal region of the stratum radiatum, respectively. 
the fact that a deficit in LTP in CPEB-1 KO mice can be overcome by stronger electrical stimuli and possibly by recruitment of preexistent CPEB-1-like proteins or transcriptional induction of others.

Unlike LTP evoked by four trains of $100 \mathrm{~Hz}$, the captured LTP was also affected in CPEB-1 KO mice. These data suggest that the full expression of the captured LTP might require CPEB-1 activity in spite of the presence of new proteins resulting from the induction of the late phase of LTP in a second pathway (Frey and Morris 1998b). These data, therefore, are consistent with the translation dependency of the captured LTP (Barco et al. 2002).

\section{CPEB-1: A New Pathway to LTP}

In oocytes and neurons, CPEB-1-mediated polyadenylation activity is contingent on a signaling pathway that results in serine 174 or threonine 171 (species-dependent) phosphorylation by the Aurora kinase (Mendez et al. 2000b; Huang et al. 2002). Interestingly, the transport of CPE-containing RNA to dendrites may not be dependent on this phosphorylation event (Huang et al. 2003). Although the BDNF-stimulated rapamycin-sensitive pathway of LTP (Tang et al. 2002) was unaffected in the CPEB-1 $\mathrm{KO}$ mice, the effect of rapamycin was partially mimicked in forms of LTP evoked by TBS. These data highlight the potential existence of two complementary molecular pathways for the regulation of localized protein synthesis: the NMDA receptor-mediated CPEB-1 pathway (Huang et al. 2002) and a rapamycin-sensitive BDNF-mediated pathway (Martin et al. 2000a; Patterson et al. 2001; Tang and Schuman 2002). There is little evidence, however, that CPEB- 1 and the FRAP/mTOR pathway are linked biochemically. Indeed, in Xenopus oocytes, they appear not to have any overlap (M. Sarkissian, R. Mendez, and J.D. Richter, in prep.). Thus, we suggest that both pathways might act synergistically.

\section{MATERIALS AND METHODS}

\section{Electrophysiology}

Transverse hippocampal slices $(400 \mu \mathrm{m})$ from C57BL/6 mice, either CPEB-1 KO or wild-type littermates (Tay and Richter, 2001), were incubated in an interface chamber at $27^{\circ}-28^{\circ} \mathrm{C}$, subfused with oxygenated artificial cerebrospinal fluid (ACSF; containing [in $\mathrm{mM}$ ] $119 \mathrm{NaCl}, 4.0 \mathrm{KCl}, 1.5 \mathrm{MgSO}_{4}, 2.5 \mathrm{CaCl}_{2}, 26.2 \mathrm{NaHCO}_{3}$, $1 \mathrm{NaH}_{2} \mathrm{PO}_{4}$, and 11 Glucose), and allowed to equilibrate for at least 90 min. fEPSPs were recorded at CA3/Schaffer collateral-CA1 synapses by placing both stimulating and recording electrodes in the stratum radiatum of CA1 area (inset in Fig. 1C). The stimulation intensity (square pulse, $50 \mu$ sec duration) was adjusted to give fEPSP slopes of approximately $40 \%$ of maximum. Baseline and after-stimuli responses were sampled once per minute at this intensity. Distinct LTP were evoked by delivering four different electrical protocols to Schaffer-collateral fibers: a single train of $100 \mathrm{~Hz}$ (1 sec, 100 pulses); four trains of $100 \mathrm{~Hz}$ (5-min intertrain interval); a single train of theta-bursts (nine bursts of four pulses at $100 \mathrm{~Hz}, 200 \mathrm{msec}$ interburst interval); or two, three, and five trains of theta-bursts (5 min intertrain interval). For two-pathway experiments, the recording electrode was placed in the middle of the stratum radiatum, whereas two stimulating electrodes were placed in the upper and lower area of the stratum radiatum, respectively. The independency between pathways was tested as described previously (Barco et al. 2002).

\section{Northern Blot}

Total RNA was extracted from brains of wild-type, CPEB-1 heterozygous, or CPEB-1 KO mice as described previously (Chomczynski and Sacchi 1987). Approximately $30 \mu \mathrm{g}$ of each RNA sample was resolved on a $1 \%$ agarose gel, blotted onto a nylon membrane, and hybridized with CPEB-1 or tubulin DNA probes.

\section{Drugs}

We used rapamycin (Calbiochem) and recombinant BDNF (R \& $\mathrm{D}$ systems). Rapamycin was dissolved in dimethylsulfoxide
( $0.002 \%$ final concentration in ACSF) and BDNF according to manufacturer's indications (R \& D systems). BDNF perfusion was done as reported previously (Kang and Schuman 1996).

\section{Statistical Analysis}

The fEPSP slopes acquired during distinct time intervals after LTP or LTD induction (i.e., 20-30, 60-90, 150-180 min, etc.) were averaged for each group (CPEB-1 KO and wild type) and compared using analysis of variance (MICROCAL ORIGIN statistical tool, Microcal Software Inc.). In all electrophysiological experiments, $n$ indicates the number of animals. In the text, the electrophysiological data were presented as mean \pm SD. The difference between two experimental data sets was considered significant at $P<.05$

\section{ACKNOWLEDGMENTS}

J.M.A. acknowledges support from the Pew Foundation for Latin American Fellows and the G. Harold and Leila Y. Mathers Charitable Foundation. E.R.K. is supported by the Howard Hughes Medical institute. J.D.R is supported by grant NS39321 from NIH.

The publication costs of this article were defrayed in part by payment of page charges. This article must therefore be hereby marked "advertisement" in accordance with 18 USC section 1734 solely to indicate this fact.

\section{REFERENCES}

Aakalu, G., Smith, W.B., Nguyen, N., Jiang, C., and Schuman, E.M 2001. Dynamic visualization of local protein synthesis in hippocampal neurons. Neuron 30: 489-502.

Angenstein, F., Greenough, W.T., and Weiler, I.J. 1998. Metabotropic glutamate receptor-initiated translocation of protein kinase p90rsk to polyribosomes: A possible factor regulating synaptic protein synthesis. Proc. Natl. Acad. Sci. 95: 15078-15083.

Arai, A., Black, J., and Lynch, G. 1994. Origins of the variations in long-term potentiation between synapses in the basal versus apical dendrites of hippocampal neurons. Hippocampus 4: 1-9.

Bailey, C.H., Bartsch, D., and Kandel, E.R. 1996. Toward a molecular definition of long-term memory storage. Proc. Natl. Acad. Sci. 93: $13445-13452$.

Barco, A. Alarcon, J.M., and Kandel, E.R. 2002. Expression of constitutively active CREB protein facilitates the late phase of long-term potentiation by enhancing synaptic capture. Cell 108: 689-703.

Beretta, L., Gingras, A.C., Svitkin, Y.V., Hall, M.N., and Sonenberg, N. 1996. Rapamycin blocks the phosphorylation of 4E-BP1 and inhibits cap-dependent initiation of translation. EMBO J. 15: 658-664.

Bienenstock, E.L., Cooper, L.N., and Munro, P.W. 1982. Theory for the development of neuron selectivity: Orientation specificity and binocular interaction in visual cortex. J. Neurosci. 2: 32-48.

Brown, E.J. and Schreiber, S.L. 1996. A signaling pathway to translational control. Cell 86: 517-520.

Brunn, G.J., Fadden, P., Haystead, T.A., and Lawrence Jr., J.C. 1997. The mammalian target of rapamycin phosphorylates sites having a (Ser/Thr)-Pro motif and is activated by antibodies to a region near its COOH terminus. J. Biol. Chem. 272: 32547-32550.

Cao, Q. and Richter, J.D. 2002. Dissolution of the maskin-eIF4E complex by cytoplasmic polyadenylation and poly(A)-binding protein controls cyclin B1 mRNA translation and oocyte maturation. EMBO I. 21: 3852-3862.

Casadio, A., Martin, K.C., Giustetto, M., Zhu, H., Chen, M., Bartsch, D., Bailey, C.H., and Kandel, E.R. 1999. A transient, neuron-wide form of CREB-mediated long-term facilitation can be stabilized at specific synapses by local protein synthesis. Cell 99: 221-237.

Castro-Alamancos, M.A., Donoghue, J.P., and Connors, B.W. 1995. Different forms of synaptic plasticity in somatosensory and motor areas of the neocortex. J. Neurosci. 15: 5324-5333.

Chicurel, M.E., Terrian, D.M., and Potter, H. 1993. mRNA at the synapse: Analysis of a synaptosomal preparation enriched in hippocampal dendritic spines. J. Neurosci. 13: 4054-4063.

Chomczynski, P. and Sacchi, N. 1987. Single-step method of RNA isolation by acid guanidinium thiocyanate-phenol-chloroform extraction. Anal. Biochem. 162: 156-159.

Crino, P.B. and Eberwine, J. 1996. Molecular characterization of the dendritic growth cone: Regulated mRNA transport and local protein synthesis. Neuron 17: 1173-1187.

Frey, U. and Morris, R.G. 1997. Synaptic tagging and long-term potentiation. Nature 385: 533-536. . 1998a. Weak before strong: Dissociating synaptic tagging and 
plasticity-factor accounts of late-LTP. Neuropharmacology 37: $545-552$.

. 1998b. Synaptic tagging: Implications for late maintenance of hippocampal long-term potentiation. Trends Neurosci. 21: 181-188.

Gartner, A. and Staiger, V. 2002. Neurotrophin secretion from hippocampal neurons evoked by long-term-potentiation-inducing electrical stimulation patterns. Proc. Natl. Acad. Sci. 99: 6386-6391.

Geppert, M., Bolshakov, V.Y., Siegelbaum, S.A., Takei, K., De Camilli, P., Hammer, R.E., and Sudhof, T.C. 1994. The role of Rab3A in neurotransmitter release. Nature 369: 493-497.

Gingras, A.C., Raught, B., and Sonenberg, N. 2001. Control of translation by the target of rapamycin proteins. Prog. Mol. Subcell. Biol. 27: 143-174

Goelet, P., Castellucci, V.F., Schacher, S., and Kandel, E.R. 1986. The long and the short of long-term memory-A molecular framework. Nature 322: 419-422.

Hake, L.E. and Richter, J.D. 1994. CPEB is a specificity factor that mediates cytoplasmic polyadenylation during Xenopus oocyte maturation. Cell 79: 617-627.

Hake, L.E., Mendez, R., and Richter, J.D. 1998. Specificity of RNA binding by CPEB: R0equirement for RNA recognition motifs and a novel zinc finger. Mol. Cell. Biol. 18: 685-693.

Huang, Y.Y. and Kandel, E.R. 1994. Recruitment of long-lasting and protein kinase A-dependent long-term potentiation in the CA1 region of hippocampus requires repeated tetanization. Learn. Mem. 1: $74-82$.

Huang, Y.S., Jung, M.Y., Sarkissian, M., and Richter, J.D. 2002. $\mathrm{N}$-methyl-D-aspartate receptor signaling results in Aurora kinase-catalyzed CPEB phosphorylation and $\alpha$ CaMKII mRNA polyadenylation at synapses. EMBO J. 21: 2139-2148.

Huang, Y.S., Carson, J.H., Barbarese, E., and Richter, J.D. 2003. Facilitation of dendritic mRNA transport by CPEB. Genes Dev. 17: 638-653.

Kang, H. and Schuman, E.M. 1996. A requirement for local protein synthesis in neurotrophin-induced hippocampal synaptic plasticity. Science 273: 1402-1406.

Kemp, N., McQueen, J., Faulkes, S., and Bashir, Z.I. 2000. Different forms of LTD in the CA1 region of the hippocampus: Role of age and stimulus protocol. Eur. J. Neurosci. 12: 360-366.

Kurihara, Y., Tokuriki, M., Myojin, R., Hori, T., Kuroiwa, A., Matsuda, Y., Sakurai, T., Kimura, M., Hecht, N.B., and Uesugi, S. 2003. CPEB2, a novel putative translational regulator in mouse haploid germ cells. Biol. Reprod. 69: 261-268.

Martin, K.C. and Kosik, K.S. 2002. Synaptic tagging-Who's it? Nat. Rev. Neurosci. 3: 813-820.

Martin, K.C., Casadio, A., Zhu, H., Yaping, E., Rose, J.C., Chen, M., Bailey, C.H., and Kandel, E.R. 1997. Synapse-specific, long-term facilitation of aplysia sensory to motor synapses: a function for local protein synthesis in memory storage. Cell 91: 927-938.

Martin, K.C., Barad, M., and Kandel, E.R. 2000a. Local protein synthesis and its role in synapse-specific plasticity. Curr. Opin. Neurobiol. 10: $587-592$.

Martin, M.E., Munoz, F.M., Salinas, M., and Fando, J.L, 2000b. Ischaemia induces changes in the association of the binding protein 4E-BP1 and eukaryotic initiation factor (eIF) $4 \mathrm{G}$ to eIF4E in differentiated PC12 cells. Biochem. J. 351: 327-334.

McGrew, L.L., Dworkin-Rastl, E., Dworkin, M.B., and Richter, J.D. 1989 Poly(A) elongation during Xenopus oocyte maturation is required for translational recruitment and is mediated by a short sequence element. Genes Dev. 3: 803-815.

Mendez, R. and Richter, J.D. 2001. Translational control by CPEB: A means to the end. Nat. Rev. Mol. Cell. Biol. 2: 521-529.

Mendez, R., Murthy, K.G., Ryan, K., Manley, J.L., and Richter, J.D. 2000a. Phosphorylation of CPEB by Eg2 mediates the recruitment of CPSF into an active cytoplasmic polyadenylation complex. Mol. Cell 6: $1253-1259$

Mendez, R., Hake, L.E., Andresson, T., Littlepage, L.E., Ruderman, J.V., and Richter, J.D. 2000b. Phosphorylation of CPE binding factor by Eg2 regulates translation of c-mos mRNA. Nature 404: 302-307.

Mendez, R., Barnard, D., and Richter, J.D. 2002. Differential mRNA translation and meiotic progression require Cdc2-mediated CPEB destruction. EMBO J. 21: 1833-1844.

Miyashiro, K., Dichter, M., and Eberwine, J. 1994. On the nature and differential distribution of mRNAs in hippocampal neurites: Implications for neuronal functioning. Proc. Natl. Acad. Sci. 91: 10800-10804.

Nguyen, P.V. and Kandel, E.R. 1996. A macromolecular synthesis-dependent late phase of long-term potentiation requiring cAMP in the medial perforant pathway of rat hippocampal slices. $J$. Neurosci. 16: 3189-3198.

Oliet, S.H., Malenka, R.C., and Nicoll, R.A. 1997. Two distinct forms of long-term depression coexist in CA1 hippocampal pyramidal cells.
Neuron 18: 969-982.

Paris, J., Swenson, K., Piwnica-Worms, H., and Richter, J.D. 1991 Maturation-specific polyadenylation: In vitro activation by p34cdc2 and phosphorylation of a 58-kD CPE-binding protein. Genes Dev. 5: $1697-1708$.

Patterson, S.L., Abel, T., Deuel, T.A., Martin, K.C., Rose, J.C., and Kandel, E.R. 1996. Recombinant BDNF rescues deficits in basal synaptic transmission and hippocampal LTP in BDNF knockout mice. Neuron 16: 1137-1145.

Patterson, S.L., Pittenger, C., Morozov, A., Martin, K.C., Scanlin, H., Drake, C., and Kandel, E.R. 2001. Some forms of cAMP-mediated long-lasting potentiation are associated with release of BDNF and nuclear translocation of phospho-MAP kinase. Neuron 32: 123-140.

Raymond, C.R., Redman, S.J., and Crouch, M.F. 2002. The phosphoinositide 3-kinase and p70 S6 kinase regulate long-term potentiation in hippocampal neurons. Neuroscience 109: 531-536.

Richter, J.D. 2001. Think globally, translate locally: What mitotic spindles and neuronal synapses have in common. Proc. Natl. Acad. Sci. 98: 7069-7071.

Richter, J.D. and Lorenz, L.J. 2002. Selective translation of mRNAs at synapses. Curr. Opin. Neurobiol. 12: 300-304.

Richter, J.D. and Theurkauf, W.E. 2001. Development. The message is in the translation. Science 293: 60-62.

Sabatini, D.M., Lai, M.M., and Snyder, S.H. 1997. Neural roles of immunophilins and their ligands. Mol. Neurobiol. 15: 223-239.

Scheetz, A.J., Nairn, A.C., and Constantine-Paton, M. 2000. NMDA receptor-mediated control of protein synthesis at developing synapses. Nat. Neurosci. 3: 211-216.

Schuman, E.M. 1997. Synapse specificity and long-term information storage. Neuron 18: 339-342.

Sossin, W.S. 1996. Mechanisms for the generation of synapse specificity in long-term memory: The implications of a requirement for transcription. Trends Neurosci. 19: 215-218.

Staubli, U. and Otaky, N. 1994. Serotonin controls the magnitude of LTP induced by theta bursts via an action on NMDA-receptor-mediated responses. Brain Res. 643: 10-16.

Stebbins-Boaz, B., Hake, L.E., and Richter, J.D. 1996. CPEB controls the cytoplasmic polyadenylation of cyclin, Cdk2 and c-mos mRNAs and is necessary for oocyte maturation in Xenopus. EMBO $J$. 15: 2582-2592.

Stebbins-Boaz, B., Cao, Q., de Moor, C.H., Mendez, R., and Richter, J.D. 1999. Maskin is a CPEB-associated factor that transiently interacts with elF-4E. Mol. Cell 4: 1017-1027.

Steward, O. 1997. mRNA localization in neurons: A multipurpose mechanism? Neuron 18: 9-12.

Steward, O. and Falk, P.M. 1986. Protein-synthetic machinery at postsynaptic sites during synaptogenesis: A quantitative study of the association between polyribosomes and developing synapses. $J$. Neurosci. 6: 412-423.

Steward, O. and Levy, W.B. 1982. Preferential localization of polyribosomes under the base of dendritic spines in granule cells of the dentate gyrus. J. Neurosci. 2: 284-291.

Tang, S.J. and Schuman, E.M. 2002. Protein synthesis in the dendrite. Philos. Trans. R. Soc. Lond. B. Biol. Sci. 357: 521-529.

Tang, S.J., Reis, G., Kang, H., Gingras, A.C., Sonenberg, N., and Schuman, E.M. 2002. A rapamycin-sensitive signaling pathway contributes to long-term synaptic plasticity in the hippocampus. Proc. Natl. Acad. Sci. 99: 467-472.

Tay, J. and Richter, J.D. 2001. Germ cell differentiation and synaptonemal complex formation are disrupted in CPEB knockout mice. Dev. Cell 1: 201-213.

Theis, M., Si, K., and Kandel, E.R. 2003. Two previously undescribed members of the mouse CPEB family of genes and their inducible expression in the principal cell layers of the hippocampus. Proc. Natl. Acad. Sci. 100: 9602-9607.

Tiedge, H. and Brosius, J. 1996. Translational machinery in dendrites of hippocampal neurons in culture. J. Neurosci. 16: 7171-7181.

Wells, D.G., Dong, X., Quinlan, E.M., Huang, Y.S., Bear, M.F., Richter, J.D., and Fallon, J.R. 2001. A role for the cytoplasmic polyadenylation element in NMDA receptor-regulated mRNA translation in neurons. J. Neurosci. 21: 9541-9548.

Winder, D.G., Mansuy, I.M., Osman, M., Moallem, T.M., and Kandel, E.R. 1998. Genetic and pharmacological evidence for a novel, intermediate phase of long-term potentiation suppressed by calcineurin. Cell 92: 25-37.

Wu, L., Wells, D., Tay, J., Mendis, D., Abbott, M.A., Barnitt, A., Quinlan, E., Heynen, A., Fallon, J.R., and Richter, J.D. 1998. CPEB-mediated cytoplasmic polyadenylation and the regulation of experience-dependent translation of $\alpha$-CaMKII mRNA at synapses. Neuron 21: 1129-1139.

Received November 21, 2003; accepted in revised form March 2, 2004. 


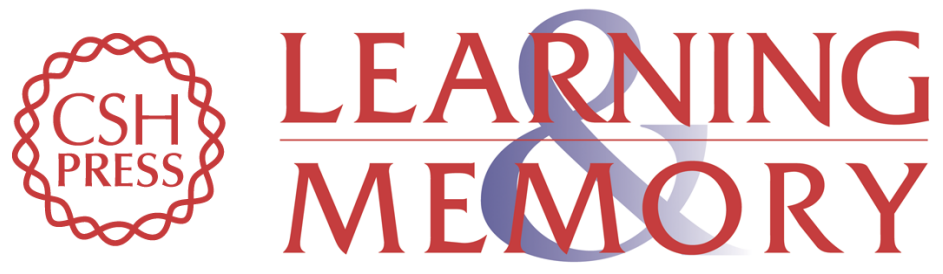

\section{Selective Modulation of Some Forms of Schaffer Collateral-CA1 Synaptic Plasticity in Mice With a Disruption of the CPEB-1 Gene}

Juan M. Alarcon, Rebecca Hodgman, Martin Theis, et al.

Learn. Mem. 2004, 11:

Access the most recent version at doi:10.1101/lm.72704

References This article cites 66 articles, 26 of which can be accessed free at:

http://learnmem.cshlp.org/content/11/3/318.full.html\#ref-list-1

License

Email Alerting Receive free email alerts when new articles cite this article - sign up in the box at the Service top right corner of the article or click here. 